\title{
THE DOCTRINE OF SUPREMACY OFEUROPEAN UNION LAW: FOUNDATIONS, SCOPE AND FUTURE PERSPECTIVES
}

The doctrine of supremacy is essential to the uniformity of the EU legal edifice. It had no formal basis in the Treaty Law but was developed by the Court of Justice of the EU by means of its conception of the "new legal order" (Costa v ENEL). Therefore, the corollary of sovereignty of the EU legal order is the supremacy of EU law: any norm of EU law takes precedence over any provision of national law. From the CJEU's perspective, supremacy entails duty for the national courts to 'set aside' any conflicting national norm when an EU rule applies in a given case. Ultimately, the acceptance and application of the supremacy of EU law are dependent on the Member States. Despite its invention, acceptance of the doctrine of supremacy has been the main challenge within the overall integration process. Recent ruling from the German Constitutional Court (the Bundesverfassungsgericht) on the legality of the European Central Bank's Programme marked that the supremacy issue cannot be put 'ad acta' and still continues to be surrounded with ambiguity and controversy against its unconditional acceptance as the CJEU requires. This paper summarizes the most remarkable aspects of the foundations of the supremacy doctrine and the conceptual basis on which the Member States accord supremacy to EU law, as well as its scope and limits. All this is necessary in order to be able to determine the perspectives for ensuring the supremacy of EU law, while highlighting its importance for the future of the European integration.

Key words: EU legal order, doctrine of supremacy, sovereignty, CJEU, national courts.

\footnotetext{
${ }^{*}$ Milena Apostolovska-Stepanoska, PhD, Professor at Iustinianus Primus Law Faculty - Ss. Cyril and Methodius University in Skopje. Email: apostolovska_mi@yahoo.com.

** Leposava Ognjanoska, LL.M., PhD Candidate at Iustinianus Primus Law Faculty - Ss. Cyril and Methodius University in Skopje. Email: lea.ognjanoska@gmail.com.
} 


\section{INTRODUCTORY REMARKS}

In the context of the international law, the European Union is a sui generis international organization. The sui generis term represents a special organizational form with its own specific features (Peročević, 2017, p.114). The main feature that the EU has in common with the traditional international organizations is that it was established as a result of international treaties too. Unlike the case is with other international organizations, accession to the Union for the Member States inevitably entails delegation or transfer of certain competences related to national sovereignty to a higher supranational structure and its institutions.

European Court of Justice (ECJ), today formally known as the Court of Justice of the European Union $(\mathrm{CJEU})^{43}$, has played a crucial role in determining the legal nature of the $\mathrm{EU}$, whose judgments have changed the nature of the organization and affected the overall process of European integration within the organization. The Van Gend en Loos judgment ${ }^{44}$ defines Community law as "a new order of international law in which the Member States have limited their sovereign rights, albeit in a restricted area, and whose subjects are not only the Member States but also their citizens". The Community is defined as a 'new order of international law', which is more than a contract exclusively aimed at mutually agreed obligations between the contracting parties (Van Rossem, 2013, p.18). By referring to the new legal order, the CJEU asserted that the Community was not just a 'traditional' or 'ordinary' international law organization and envisaged its more independent status as well as greater impact on the national legal systems of the Member States. The term 'Community of $\mathrm{Law}^{35}$ emphasized the role of law in the European unification project which has been described by scholars precisely as 'integration through law' (Vauchez, 2008, p.1).

Hence, the relationship between the EU law and national law had to be defined. Once again, the CJEU, through its creative and extensive interpretation of the Treaties proved to be an important catalyst for the integration process (Svensson, 2008, p.4). On the basis of its conception of the 'new legal order' the CJEU developed the doctrine of supremacy ${ }^{46}$ of Community law which had no previous formal basis in the European Community Treaty. Stating that the aim of creating a uniform common market between different states would

${ }^{43}$ Prior to the Lisbon Treaty the Community Courts comprised the European Court of Justice (ECJ), the Court of First Instance (CFI) and judicial panels. Their nomenclature has been changed by the Lisbon Treaty. Pursuant to Article 19 (1), the Court of Justice of the European Union shall consist of the Court of Justice, the General Court and the specialized courts. Given the jurisdiction of these courts established by the Lisbon Treaty, especially in the preliminary ruling process, when it comes to the European Court of Justice or Court of Justice, the General Court is usually included. In order to ensure consistency, this paper uses the Lisbon nomenclature, but one must have in mind that judgments prior to the Lisbon Treaty were delivered by the European Court of Justice, as named at the time.

${ }^{44}$ Case C-26/62, NV Algemene Transporten Expeditie Onderneming van Gend en Loos v Nederlandse Administratie der Belastingen [1963] ECR 1.

${ }^{45}$ This term was popularized by Walter Hallstein (1901-1982) as the first President of the European Commission (1958-1967) who referred to the term 'community of law' in a speech delivered in March 1962.

${ }^{46}$ Term 'primacy' is also used to denote the same doctrine but some authors make distinction between the both regarding their content and scope. See more at Avbelj, M. (2011). Supremacy or Primacy of EU Law (Why) Does It Matter?. European Law Journal, Vol. 17, No. 6, pp. 744-763. 
be undermined if EU law could be made subordinate to national law of the various states (Craig \& De Búrca, 2011, p.256), Costa $v$ E.N.E.L. judgment ${ }^{47}$ claimed that the corollary of sovereignty of the EU legal order is the supremacy of EU law: any norm of EU law takes precedence over any provision of national law.

From the CJEU's perspective, the absolute supremacy of EU law was vital in order to 'preserve the uniformity and efficacy of Community law in all the Member States' (Weatherill, 1993, p.316). Supremacy entails duty for the national courts to 'set aside' any conflicting national norm when an EU rule applies in a given case. Ultimately, the acceptance and application of the supremacy of EU law are dependent on the Member States. However,, the acceptance of the doctrine of supremacy has been the main challenge in that regard. It follows that the evolutionary nature of the doctrine of supremacy is necessarily bidimensional - one dimension is the elaboration of the parameters of the doctrine by the CJEU, while the second dimension refers to the reception and affirmation of the supremacy notion by the national courts of the Member States (Weiler, 1981, p.275-276).

A recent ruling of the German Constitutional Court (the Bundesverfassungsgericht or "BVerfG") on the legality of the European Central Bank's Programme regarding the CJEU's judgment in Weiss (Case C-493/17), shows that the supremacy issue cannot be put ad acta and still continues to be marked with ambiguity and controversy against its unconditional acceptance as required by the CJEU. The Karlsruhe judges dismissed the CJEU ruling in the ECB's favor, thus defying the doctrine of supremacy of EU law and the authority of the Luxembourg- based judiciary to have the final say on this matter, thus opening the door to potential legal challenges against the EU from other countries.

This paper summarizes the most remarkable aspects of the foundations of the supremacy doctrine and the conceptual basis on which the Member States accord supremacy to EU law, as well as its scope and limits. All this is necessary in order to be able to determine the perspectives for ensuring the supremacy of EU law, while highlighting its importance for the future of the European integration in the light of the increasingly heated arguments for and against the European Union. Finally, this approach is especially important to be examined in the light of the enlargement process and accession of candidate countries, such as the Republic of North Macedonia.

\section{CJEU'S DESIGN OF THE EU LAW SUPREMACY}

At the time of its 'invention' - the early years of the Community's existence- the doctrine of supremacy was not prescribed in the European Community Treaty (ECT), but the CJEU consistently held that it was implied in the Treaty (Vincenzi and Fairhurst, 2002, 185), on the basis of its conception of how the 'new legal order' should be developed (Craig \& De Burca, 2011, p.256). The CJEU touched upon this issue in Van Gend en Loos, emphasizing that EU law was not just a tool of international law, but had direct effect [under certain requirements] (Douglas, 2002, p.55) when it stated that the Community constituted a new legal order of international law for the benefit of which the states had limited their sovereign rights.

${ }^{47}$ Case C-6/64, Flaminio Costa v ENEL [1964] ECR 585, 593. 


\subsection{The Invention of the Doctrine of Supremacy}

The issue of supremacy was directly addressed in Costa v. ENEL where on the side of the facts Flaminio Costa claimed that a subsequent Italian statute 'lex posterior' breached Articles 37, 93, 95 and 102 of the EC Treaty and the Giudice Conciliatore of Milan, referred the issue to the CJEU under Article 234 (ex Article 177). The CJEU responded to the argument that its preliminary ruling would be of no relevance to the case at hand because the Italian courts would be bound to follow national law (Craig, 2004, p.35) and it opposed the doctrines such as lex posteriori derogat lege priori and lex specialis derogat lex generali. This time the doctrine of EU supremacy was firmly established and CJEU developed profound legal argumentation to justify its position, which can be divided into two categories: a) those regarding the nature of the Community (now the Union); and (b) those regarding the purpose of the Community (now the Union) (Steiner et al, 2003, p.67). Regarding the nature of the Community (Union) law, the Court distinguished the Treaty from other international treaties since the EEC (EU) "has created its own legal system which became an integral part of Member States and which their courts are bound to apply" (Costa, 1964, ECR 586). Moreover, it held that:

"by creating a Community of unlimited duration, having... real powers stemming from limitation of sovereignty or a transfer of powers from the States to the Community, the Member States have limited their sovereign rights, albeit within limited fields, and have thus created a body of law which binds both their nationals and themselves" (Costa, 1964, ECR 593).

The CJEU's conception of the 'new legal order' was expanded by stating its 'independent nature' which was voluntarily established by the Member States at the cost of 'permanent limitation of their sovereign rights' (Steiner et al, 2003, p.67). To sustain this statement, the Court referred to Article 249 (ex Article 189), whereby a regulation 'shall be binding' and 'directly applicable in all Member States' and thus confirmed 'the precedence of Community law'. As the aims of the Community are concerned, the Court's arguments were more functional and pragmatic - "the executive force of Community law cannot vary from one State to another in deference to subsequent domestic laws, without jeopardizing the attainment of the objectives of the Treaty set out in Article 5(2)" (Costa, 1963, ECR 594). The Court stated that the aims of the Treaty were integration and cooperation, and their achievement would be undermined by one Member State refusing to give effect to a Community (Union law) which should uniformly and equally bind all (Craig \& De Búrca, 2011, p.258). The rule of supremacy guarantees that the doctrine of direct effect has its intended effect: to make Community law uniform and effective (Svensson, 2008, p.19).

Finally, from all these observations the Court stated that:

"the law stemming from the Treaty, an independent source of law, could not, because of its special and original nature, be overridden by domestic legal provisions, however framed, without being deprived of its character as Community law and without the legal basis of the Community itself being called into question" (Costa, 1963, ECR 594).

It can be concluded that the Court established its conception of the new legal order on the basis of the permanent limitation of the sovereign rights by the Member States in certain 
fields of competence, which then had transferred sovereignty to the Union institutions. Therefore, any subsequent unilateral act incompatible with this concept cannot prevail and this provision is 'subject to no reservation'. According to the Court's observations, the doctrine of supremacy is applicable regarding the policy areas that fall within the Union competences and this rule must be respected in the event of any such conflict between national and EU law.

By establishing the doctrine of supremacy, as it was elaborately spelled out, the Court also affirmed the rule of law concept, which was later promoted by the Lisbon Treaty as one of the founding values of the EU. The rule-of-law oriented interpretation by the Court is reflected in its aspiration to prevent different rules for resolving the clashes between national and EU law, faced with the fact that Community law could, but should not, be different in the different Member States. CJEU wanted to establish general supremacy of all EU law, as it held that Community law 'cannot be overridden by domestic legal provisions, however framed', but in its argumentation it referred to the application of regulations as a source of EU law. The national courts mainly apply supremacy by virtue of the authority of their national constitutions and consider supremacy and direct effect of EC law as concepts stemming primarily from national constitutions (Witte, 1999, p.199). Having in mind the specific foundations of the doctrine of supremacy, it was intriguing what would be the outcome if a constitutional law of a Member State was in breach of EU law.

\subsection{Evolution of the EU Law Supremacy and the Formula for Its Application}

The conflict between Member State's constitutional law and EU law was addressed by CJEU in Internationale Handelsgesellschaf $t^{48}$ by stating that not even a fundamental rule of national constitutional law could be invoked to challenge the supremacy of the EU law (then Community law). Under the German Constitution, any ordinary law incompatible with the German Constitution was invalid, since the Constitution is the highest source of law. In this case, the Court responded that "the validity of a Community measure or its effect within a Member State cannot be affected by allegations that it runs counter to either fundamental rights as formulated by the constitution of that State or the principles of a national constitutional structure". This statement was based on the argument that, with reference to the fundamental rights under the German Constitution, protection of the same rights is one of the main aims of the Treaty. The legality of a Community act cannot be judged in the light of national law (Steiner et al, 2003, p.67) as it "would have an adverse effect on the uniformity and efficacy of Community law" (Internationale Handelsgesellschaft, 1970, ECR 1125).

Another conclusion that can be drawn from the Costa judgment is that application of the doctrine of supremacy is referred to the national courts of the Member States which should recognize the supremacy of EU law, although no 'recipe' was provided. The context in which this doctrine was invented also must be taken into consideration - the early

${ }^{48}$ Case 11/70, Internationale Handelsgesellschaft mbH v. Einfur und Vorratsstelle fur Getreide und Futtermittel, [1970] ECR 1125. 
years of the European unification project when the creation of the common market was the main goal. So the doctrine of supremacy was further developed by the Court as it was given added force in the Simmenthal case ${ }^{49}$. This time the CJEU provided such a 'formula' for the application of the doctrine of supremacy stating that "every national court must, in a case within its jurisdiction, apply Community law in its entirety and protect rights which the latter confers on individuals and must accordingly set aside any provision of national law which may conflict with it, whether prior or subsequent to the Community rule" (Simmenthal, 1978, ECR 629). It also stressed that in order to give full effect to the Community provisions, the Court should refuse to apply "any conflicting provision of national legislation, even if adopted subsequently, and it is not necessary for the court to request or await the prior setting aside of such provision by legislative or other constitutional means". Supremacy entails duty for the national courts to 'set aside' any conflicting national norm when an EU rule applies in a given case. But, as this doctrine was developed, the requirement to 'set aside' conflicting national law did not entail an obligation to nullify national law, which may continue to apply in any situation that is not covered by a conflicting provision of EU law (Craig \& De Burca, 2011, p.256). Yet, this 'mere' duty to disapply the conflicting norm of national law is only a minimum requirement - "EU law norms 'not only by their entry into force render automatically inapplicable any conflicting provision of current national law but... also preclude the valid adoption of new national legislative measures to the extent to which they would be incompatible with Community provisions" (Simmenthal, 1978, ECR 632). However, it also entails duty for other national authorities such as those on the legislative level, not to adopt laws that are inconsistent with binding rules of Union law and a duty to modify the laws that prove to be inconsistent, especially in cases when the Union law is intended to harmonize national legislation (Witte, 2011, p.340-341). In Factortame ${ }^{50}$ the Court held that there should be a provision for state liability also where the national legislature was responsible for the breach of EC law and thus required national courts to do more than just 'set aside' national laws.

\subsection{Attempts for Codification of the Supremacy Doctrine}

The doctrine of supremacy was introduced by the Court of Justice in a consistent line of case law and it 'constitutionalised' the EC Treaty. The Maastricht Treaty also introduced the 'pillar structure' of the EU, by distinguishing the First Pillar from the Second and Third Pillar as parts of the EU Treaty that did not share many of these special supranational characteristics of the EC Treaty. In the context of the evolution of the doctrine of supremacy, it raised a question of its scope as to whether the EU Treaty has created a specific legal order like the EC Treaty. National judgments on the implementation of the European Arrest Warrant, which is a Framework Decision adopted within the Third Pillar, did not recognize supremacy of Third Pillar 'law'. The optimistic approach towards 'The Future of Europe' in 2002/2003 embedded in the Treaty establishing a Constitution for Europe

${ }^{49}$ C-106/77, Amministrazione delle Finanze dello Stato v. Simmenthal SpA, [1978] ECR 629.

${ }^{50}$ Case C-213/89, R v. Secretary of State for Transport, ex parte Factortame Ltd. and Others, [1990] ECR I-2433. 
of 2004, formally incorporated the supremacy doctrine in Article I-6: "The Constitution and law adopted by the institutions of the Union in exercising competences conferred on it shall have primacy over the law of the Member States". This 'codification' of the supremacy doctrine actually reflected the existing case-law of the CJEU and did not bring any changes to the existing relationship between EU law and national law (Witte, 2011, p.345). Having in mind the destiny of the EU Constitution, for which it was decided to be turned into a de-constitutionalized Reform Treaty, this provision was simply dropped from the Lisbon Treaty on order of the European Council in 2007 and replaced by a Declaration concerning primacy. Declaration 17 Concerning Primacy stated that

"Conference recalls that, in accordance with well settled case law of the Court of Justice of the European Union, the Treaties and the law adopted by the Union on the basis of the Treaties have primacy over the law of Member States, under the conditions laid down by the said case law".

Opinion of the Council Legal Service of 22 June 2007, , reiterated the supremacy of EC law established by the Court of Justice in Costa judgment as a cornerstone of Community law and assured that "the fact that the principle of primacy will not be included in the future treaty [Lisbon Treaty] shall not in any way change the existence of the principle and the existing case-law of the Court of Justice". Giving thought to the legal power of the declaration as an instrument, removal of the supremacy doctrine from the Treaty has not removed the ambiguity regarding the conceptual basis for acceptance of supremacy, its scope and limits. Despite its invention, the acceptance and application of the supremacy of EU law are the main challenges in that regards and remain dependent on the Member States.

\section{3. "JUDICIAL DIALOGUES”: RECEPTION OF THE DOCTRINE OF SUPREMACY BY NATIONAL COURTS}

The doctrine of supremacy of the EU law founded by the Court of Justice of the EU can have impact on the legal reality only through the attitude of the national courts and other institutions of the Member States. National courts enjoy a key role in the daily application of EU law, as they function as EU courts that apply EU legislation in national contexts (Paunio, 2010 , p.2). It is worth to mention in that regard, that the involvement of national courts in the preliminary ruling procedure (Article 267 Treaty on the Functioning of the European Union [TFEU]) has been crucial for the ability of the CJEU to promote legal integration (Weiler 1994; Alter 1996; Mattli and Slaughter 1998; Davies 2012). In this procedure, the CJEU engages in a constant dialogue with national courts to a certain extent (Rosas, 2007, p.4) and it has been established as an instrument to further develop the law. Hence, Costa $\checkmark$ ENEL was also a result of preliminary ruling procedure that was presented as a challenge to the Court's jurisdiction and seized as an opportunity to formulate the supremacy principle. The justification of the fundamental principle of supremacy is therefore close to the purpose of Article 267 and there is clear mutual dependence between preliminary rulings and supremacy of EU law (Norberg, 2006, p.16). Although, in accordance with the EU law supremacy, the CJEU possesses hierarchical authority over national courts in questions related to EU law, this does not simply imply that the national courts always 
fully agree on the given interpretations, especially in cases related to human rights such as Solange and Maastricht decisions of the German Federal Constitutional Court known as BVerfGE (Norberg, 2006, p.11). Within the preliminary ruling procedure inter alia national courts also elaborated their basis for acceptance of the supremacy doctrine and set certain limitations. In continuation, the reception of the doctrine of supremacy of the EU law at national level will be examined.

\subsection{Grounds for Acceptance of the Supremacy Doctrine}

Accession to the Union for the Member States inevitably entails delegation or transfer of certain competences related to national sovereignty to this supranational structure and the Member States accept the supremacy of EU law. However, it cannot be expected that the transposition of the EU law into different legal systems will produce identical or even similar results in all those systems. The conceptual basis on which the Member States accord supremacy to EU law is the first parameter for examination of the reception of the doctrine of supremacy: they may choose to do so because they accept the Court of Justice's communautaire reasoning in Costa v.ENEL, or because of a provision within their own national legal order (Craig, 2004, p.44).

Regarding the first approach, the principle of supremacy is essential to the uniformity of the EU legal edifice and ensuring its efficacy in all Member States. On the basis of the communautaire reasoning, Belgian Cour de Cassation accorded such supremacy to EC law in the Le Ski case ${ }^{51}$. It held that in the event of a conflict between a norm of international treaty which produces direct effect in the domestic legal order and domestic law, the treaty must prevail. Moreover, the Belgian Cour affirmed that the EC treaties have constituted a new legal system since the Member States have restricted the exercise of their sovereign powers in the areas determined by those treaties. On the other side, Belgian Constitutional Court - Cour d'Arbitrage granted supremacy to the constitution in regard to the international treaties, but interpreted Le Ski case as applicable only when clash between national law provision and EC Treaty occurs.

However, most of the Member States grounded the acceptance of EU law supremacy in national constitutional provisions on the basis of the dualism concept. In the case of France, the supremacy accorded to the EU law was not based on the inherent nature of EU law, but under the authority of their own national legal order - Articles 55 and 88-1 of the French Constitution (Witte, 1991, p.1-22). French Cour de Cassation in Café Jacques Vabres ${ }^{52}$ stated that the Constitution itself admitted priority to a 'properly ratified international act' in case of clash with 'internal law' since its Article 55 provided for the primacy of certain international treaties over domestic law. The Conseil d'Etat in Nicolo ${ }^{53}$ also grounded its decision on the same constitutional provision, motivated by earlier decisions of the

\footnotetext{
${ }^{51}$ Fromagerie Franco-Suisse Le Ski v. Etat Belge [1972] CMLR 330.

52 Dec of 24 May 1975 in Administration des Douanes $v$ Société 'Cafés Jacques Vabre' et SARL Weigel et Cie [1975] 2 CMLR 336.

${ }^{53}$ Dec of 20 Oct 1989 in Raoul Georges Nicolo [1990] 1 CMLR 173.
} 
Conseil Constitutionnel, which indicated that it was for the other French courts to ensure that international treaties were applied (Oliver, 1994, p.10). In a similar manner, German Federal Constitutional Court (BVerfG) relied on constitutional provisions as dominant rationale for the acceptance of EU law supremacy, basing its argumentation on some version of the communautaire thesis. Starting from the Court of Justice's premise that "the Union could not exist as a legal community if the uniform effectiveness of Union law were not safeguarded in the Member State", BVerfG in Honeywell ${ }^{54}$ stated that such transfer of sovereign power to the EU by Germany as a Member State was exercised in accordance with Article 23.1 of the Basic Law. Finally, it concluded that 'unlike the primacy of application of federal law, as provided for by Article 31 of the Basic Law for the German legal system, the primacy of application of Union law cannot be comprehensive'. Although it accepted the doctrine of supremacy, this reasoning by BVerfG reflected the rich jurisprudence in which the German courts have articulated different limits to its application. Similar reservations regarding unconditional acceptance of the EU law supremacy were also expressed by the Italian Courte Constituzionale in Frontini ${ }^{55}$, while accepting that on the basis of the Article 11 of the Constitution "Italy agrees, on conditions of equality with other States, to the limitations of sovereignty that may be necessary to a world order ensuring peace and justice among the Nations".

Having in mind the significance of the EU law supremacy for the uniformity of EU's legal edifice, another interesting issue is the acceptance of this doctrine by the 'newer Member States' - Central and Eastern European countries that joined the EU on the basis of the conditionality policy. At that time, EU law supremacy was already established as part of the acquis communauraire and one would therefore expect the supremacy doctrine to be a part of the accession criteria. However, none of the Accession Treaties contained such provisions and CEE Constitutional Courts themselves have proven to be important interlocutors in the ongoing supremacy discourse. According to the comparative analyses delivered by Claes (2005, p.81-125) constitutional clauses allowing for the attribution of state powers to international organizations or more explicitly to the EU have had the effect of securing supremacy of the Union law. Such provision is contained in Article 90(1) of the Polish Constitution that authorizes delegation of competences of State organs to international organizations in relation to certain matters, while Article 91(2) more precisely accords precedence of international agreements over statutes. Similar 'enabling clauses' are contained in Czech Constitution in Articles 10 and 10a, as well as in Hungarian Constitution (Amendment of 12 December 2002) that provides for strict 'EU' clause instead of 'international organization' approach (Albi, 2005, p.126).

The transfer or delegation of powers to the EU by its newest Member State - Croatia is also granted on the basis of the Croatian Constitution whose Article 143(2) states that "Republic of Croatia shall confer upon the institutions of the EU the powers necessary for the enjoyment of rights and fulfillment of obligations ensuing from membership". Pursuant to Article 145 of the said Constitution, EU legal acts have to be applied 'in accordance with

\footnotetext{
${ }^{54}$ BVerfG, 2 BvR 2661/06, 6 July 2010.

${ }^{55}$ Frontini v Ministero delle Finanze [1974] 2 CMLR 372.
} 
the acquis communautaire' and it indirectly lays down the application of the principles of EU law such as supremacy (Goldner Lang et al, 2019, 1146).

\subsection{Challenges and Limits to Acceptance of EU Law Supremacy}

The conceptual basis for acceptance of the supremacy of EU law is still a live issue in all Member States. Most of the Member States were in the belief that the relationship between the EU law and national law was a matter of the constitutional rules of the State concerned. This approach imposed certain reservations that have been made by some national constitutional courts as to whether the national legal order places limits on its acceptance of EU law supremacy derived from its own national constitution and/or national fundamental rights. As it was already mentioned above, the Court of Justice envisaged absolute supremacy of the EU law by virtue of the inherent nature of the new legal order, but the acceptance of the doctrine has not been unconditional and comprehensive.

French Conseil constitutionnel and Conseil d'Etat both held that it is the Union legal order which is integrated into the national order on the basis of the Constitution that remains the norm determining the relationship between the legal systems (Charpy, 2007, p.459). The duty to implement the Union law together with the principle of its supremacy does not alter the place of the Constitution at the apex of the internal legal order.

But it was the German Constitutional Court (BVerfGE) that has played an eminent role for the constitutional foundations of Germany's participation in the ongoing process of European integration, but also for the development of the jurisprudence in other EU Member States (Grimm et al, 2019, p.414). As it was mentioned above, it was the Article 23(1) of the German Basic Law that stipulates a positive obligation for Germany's state institutions to 'participate in the development of the European Union' with the constitutional objective of 'establishing a united Europe' (Grimm et al, 2019, p.417). Together with Articles 24 and 25 of the German Constitution, these provisions represent the conceptual basis for acceptance of the EU law supremacy. But the German courts within the well-known canon of relevant cases such as Solange $I^{56}$, Solange $I^{57}$, Mastricht ${ }^{58}$, Lisbon ${ }^{59}$ and many others, have laid down limits to the acceptance of the supremacy doctrine and to the overall process of European integration in that regard. These limits relate to the fundamental rights, competence and constitutional identity. As a reaction to the CJEU's reasoning in Internationale Handelsgesellschaft mentioned above, BVerfG in Solange I held that Article 24 of the German Constitution (Article 24) nullifies any treaty amendment which would destroy the identity of the valid constitutional structure like the protection of the fundamental rights as an' inalienable essential feature' of it. The Court concluded that the Community at that time did not have a 'codified catalogue of fundamental rights. Therefore, in the event of conflict, the protection of fundamental rights in the German Constitution would prevail over EU law.t. But given the

\footnotetext{
${ }^{56}$ BVerfG, case 2 BvL 52/71, Solange I, order of 29 May 1974, BVerfGE 37, 271.

${ }^{57}$ BVerfG, case 2 BvR 197/83, Solange II, order of 22 Oct. 1986, BVerfGE 73, 339.

${ }^{58}$ BVerfG, case 2 BvR 2134, 2159/92, Treaty of Maastricht, judgment of 12 Oct. 1993, BVerfGE 89, 155.

${ }^{59}$ BVerfG, case 2 BvE 2/08 et al., Treaty of Lisbon, judgment of 30 June 2009, BVerfGE 123, 267.
} 
development by the CJEU of the fundamental rights doctrine, Solange II decision stated that so long as (in German solange) EC had a level of protection of fundamental rights that is substantially in concurrence with the protections afforded by the German constitution, it would no longer review specific Community acts in light of that constitution. On the occasion of reviewing the constitutionality of the Maastricht Treaty ratification, the BVerfG articulated a competence-based limit to its acceptance of EU supremacy and regarded itself as possessing the jurisdiction to review the actions of European 'institutions and agencies' in order to ensure that the EU did not stray beyond the powers expressly conferred upon it in the Treaties. This issue of who has the ultimate authority to define the allocation of competence as between the EU and the Member States is known as Kompetenz-Kompetenz. In Lisbon decision the BVerfG had reaffirmed its authority to engage in ultra vires review in relation with the constitutional identity known as the identity lock (Craig \& De Burca, 2011, p.279). The judicial dialogue between the BVerfG and the CJEU revolving around questions of constitutional identity culminated as the BVerfG in its judgment from May 2020 ruled that the Public Sector Purchase Programme (PSPP) of the European Central Bank (ECB) was contrary to the German Federal Constitution, the Grundgesetz ${ }^{60}$. This decision was passed following a CJEU's preliminary ruling requested by the BVerfG on questions related to whether the relevant decisions of the ECB amounted to ultra vires acts and were infringing German constitutional identity (Mohay, 2020). German Federal Constitutional Court proclaimed that the CJEU did not scrutinize the ECB's competences sufficiently and authorised the ECB "to pursue its own economic policy agenda". Moreover, it found that it was also" the CJEU who acted ultra vires, which is why, in that respect, its Judgment has no binding force in Germany".

So if the constitution is seen as a basis for recognizing the supremacy of Union law, then the absolute supremacy postulated by CJEU is only possible by way of an 'auto-limitation' constitutional clause (Witte, 2011, p.355). Such provision is contained in Article 120 of the Dutch Constitution that prohibits national courts from reviewing the constitutionality of Treaty provisions and of decisions of international organizations, and thereby ensures the absolute supremacy of Treaties once they have been properly ratified.

Italian constitutional case law also represents a similar point of view. Fragd ${ }^{61}$ decision is a further development of the doctrine implicitly contained in Frontini (Cartabia, 1990, p.183) but unlike Frontini, the latter shows that the Constitutional Court is willing to test the consistency of individual rules of Community (Union) law with the fundamental principles for the protection of human rights that are contained in the Italian Constitution (Gaja, 1990, p.93-34). More recently, the tension between the supremacy and effectiveness of EU law, on the one hand, and the (higher) protection of fundamental rights guaranteed by the national constitutions and respect for the national identity of the Member States, on the other hand, was challenged in Taricco $\mathrm{I}^{62}$ and Taricco $\mathrm{II}^{63}$ judgments. In Taricco

\footnotetext{
${ }^{60}$ BverfG, Judgment of the Second Senate of 05 May 2020 - 2BvR 859/15.

${ }^{61}$ Spa Fragd v Amministrazione delle Finanze, Dec 232 of 21 Apr 1989 (1989) 72 RDI.

${ }^{62}$ Case C-105/14, Ivo Taricco and Others, ECJ (Grand Chamber) 8 September 2015.

${ }^{63}$ Case C-42/17, M.A.S. and M.B., ECJ (Grand Chamber) 5 December 2017, also known as Taricco II.
} 
II, however, the CJEU decided to approach this tension in a constructive way and settle the longstanding dispute with Italian courts - transforming what could have been a war between courts into a dialogue between them (Maesa, 2018, p.50), as it allowed the Italian authorities to apply their national standard of protection of the legality principle, even if it results in "a national situation incompatible with EU law". This decision also tackled the Komptenz-Komptenz issue in a certain way.

The 'Supremacy saga' is especially interesting in the case of Central and Eastern European Constitutional Courts that have set themselves in the role of protectors of the constitutional values, defining the limits of the penetration of EU law into the domestic constitutional order. Since the membership of the EU has been seen by the CEE countries as an instrument for securing democracy and human rights, it seems paradoxical that their constitutional courts use the human rights and democracy arguments to derogate from the EU law supremacy doctrine. Sadurski describes this approach as a democracy paradox whereby the consolidation of democracy that was used as a motor for European integration in these Member States is now being used as an argument against the legal integration of these countries into the Union (2006, p.36). Very illustrative example in that regard is the decision of the Polish Constitutional Tribunal on the European Arrest Warrant $^{64}$ that found the Polish law implementing the Framework Decision 2002/584/ JHA unconstitutional as it was contrary to the constitutional prohibition on extradition of Polish nationals enshrined in Article 55 of the Constitution.

Croatian Constitutional Court also seized the opportunity ${ }^{65}$ to determine that the Constitution is, by its legal nature, supreme to EU law (Goldner Lang et al, 2019, p.1147).

Finally, the present candidate countries, such as the Republic of North Macedonia, are expected in the future to take part in this 'judicial dialogue' on the supremacy doctrine, mainly through the role of the Constitutional Court as a main interlocutor. Current constitutional norm on the status of the international treaties, contained in Article 118 of the North Macedonia Constitution, provides that "international treaties ratified in accordance with the Constitution are part of the internal legal order and cannot be changed by law". Hence, ratified international treaties are supreme in relation to the national laws, but not regarding the Constitution. Among other steps for Europenization of the Macedonian constitutional order in the light of the accession to the EU, Constitution of the Republic of North Macedonia should be also amended so as to provide constitutional basis for the delegation of power and transfer of sovereignty to this supranational organization (Shkarikj, 2008, p.51). Having in mind the importance of the EU membership for the Republic of North Macedonia and the persistence in the accession process that has officially started in 2005 , when it was granted the candidate country status, the judges should not oppose the acceptance and application of the supremacy of EU law in the context of the democracy paradox explained by Sadurski. For that purpose, judges should possess extensive knowledge in EU law and be trained in the manner of European judges. Ensuring stronger acceptance

\footnotetext{
${ }^{64}$ Polish Constitutional Tribunal, 27 Apr 2005, No P 1/05.

${ }^{65}$ Judgment U-VIIR-1159/2015, 8 April 2015 of the Croatian Constitutional Court; Judgment U-VIIR-1158/2015, 21 April 2015 of the Croatian Constitutional Court.
} 
of the doctrine of supremacy and more uniform application by the Member States is a crucial prerequisite for smooth functioning and further development of the European integration and its legal system.

\section{CONCLUSION}

The establishment and functioning of a common legal order taking precedence over the legal systems of EU Member States has relied essentially on two pillars, namely the principle of supremacy of EU law and a close cooperation between national courts and the CJEU regarding its acceptance and transposition. As the CJEU envisioned the corollary of sovereignty of the EU legal order is the supremacy of EU law. However, this does not imply that national judges have blindly and unconditionally accepted the supremacy of EU law that still clearly retains its bi-dimensional character. The application of the supremacy principle cannot be separated from the transfer of competences and sovereignty of Member States to the Union and the very depth of the integration process. The most recent ruling from the BVerfG on the legality of the Union's fiscal policy showed that the supremacy issue cannot be put ad acta and still continues to be surrounded with ambiguity and controversy against its unconditional acceptance as the CJEU requires. It has eroded the judicial dialogue between national courts and Union's Court and the authority of the EU's jurisdiction. But, at the same time, the prompt reaction of the EU institutions confirms the significance of this principle for the overall functioning of the Union and the evolution of the European integration process. In its statement the CJEU recalled that "divergences between courts of the Member States as to the validity of such acts would indeed be liable to place in jeopardy the unity of the EU legal order and to detract from legal certainty". It reminded the Member States that this principle is the only way of ensuring their equality in the Union they themselves have created. Commission President von der Leyen even announced that launch of an infringement procedure was under consideration, as an inevitable course of action. One possible path, as suggested by Joseph Weiler and José Luis Requejo, may be the creation of a constitutional chamber within the CJEU, an ad hoc body composed of $\mathrm{EU}$ and national judges that rules upon the request of a supreme or constitutional court when it considers that the EU has manifestly exceeded its powers (as stated by Sarmiento and Utrilla, 2020). Whatever path it may take, it will clearly determine the future of the European integration process based primarily on the transfer of sovereignty of the Member States vis a vis the European Union, as further strengthening of the doctrine of supremacy is necessary to keep the unity of the EU law, ensuring legal certainty and equality of the Member States in the EU. 


\section{LIST OF REFERENCES}

Albi, A. 2005. EU Enlargement and the Constitutions of Central and Eastern Europe, Cambridge: Cambridge University Press.

Albi, A. 2006. Supremacy of EC Law in the New Member States: Bringing Parliaments into the Equation of 'Co-operative Constitutionalism'. Hanover: CONNEX Workshop. Available at: http://www.mzes.uni-mannheim.de/projekte/typo3/site/fileadmin/research\%20 groups/2/Hanover2006/Albi\%20EuConst\%20Supremacy\%20Hanover.pdf(03.09.2020).

Alter, K. J. 1996. The European Court's Political Power. West European Politics, 19(3), pp.458-487. DOI: 10.1080/01402389608425146.

Cartabia, M. 1990. The Italian Constitutional Court and the Relationship Between the Italian Legal System and the European Community. Michigan Journal of International Law, 12(1), pp.173-203.

Cenevska, I. 2007. In search of a 'recipe' for supremacy: The first experiences in the application of the doctrine in some of the new Member States (Hungary, Poland and the Czech Republic)/master thesis. Bruges: College of Europe.

Charpy, C. 2007. The Status of (Secondary) Community Law in the French Internal Order. European Constitutional Law Review, 3(03, pp.436 - 462. DOI: 10.1017/ S1574019607004361

Claes, M. 2005. Constitutionalizing Europe at its Source: The 'European Clauses' in the National Constitutions: Evolution and Typology. Yearbook of European Law, 24(1), pp.81-125. DOI: $10.1093 /$ yel/24.1.81

Craig, P. and De Búrca, G. 2011. EU Law: Text, Cases and Materials. Oxford/New York: Oxford University Press.

Craig, P. The ECJ, National Courts, and the Supremacy of Community Law. In: Miccü, R and Pernice, I. (eds.), The European Constitution in the Making, Baden-Baden: Nomos Verlagsgesellschaft, pp.35-52.

Davies, G. 2012. Activism Relocated. The Self-Restraint of the European Court of Justice in Its National Contex. Journal of European Public Policy, 19(1), pp.76-91. DOI: 10.1080/13501763.2012.632146.

Dorani, S. 2020. The Supremacy of EU Law over National Law: The ECJ's Perspectives. Political Reflections, 6(1), pp.15-21. Available at: http://politicalreflectionmagazine. com/wp-content/uploads/2020/01/PR_Issue22.pdf (14.08.2020).

Douglas, S. 2002. Constitutional Law of the European Union. London: Longman Pearson Publishers.

Gaja, G. 1990. New Developments in a Continuing Story: The Relationship between EEC Law and Italian Law. Common Market Law Review, 27(1), pp.83-96. 
Goldner Lang, I., Đurđević, Z. And Mataija, M. 2019. The Constitution of Croatia in the Perspective of European and Global Governance. In: Albi A., Bardutzky S. (eds.), National Constitutions in European and Global Governance: Democracy, Rights, the Rule of Law. The Hague: T.M.C. Asser Press, pp.1139-1177.

Grimm, D., Wendel, M. and Reinbacher, T. 2019. European Constitutionalism and the German Basic Law. In: Albi A., Bardutzky S. (eds.), National Constitutions in European and Global Governance: Democracy, Rights, the Rule of Law. The Hague: T.M.C. Asser Press, pp.407-492.

Leijon, K. 2020. National courts and preliminary references: supporting legal integration, protecting national autonomy or balancing conflicting demands?. West European Politics, 43. DOI: $10.1080 / 01402382.2020 .1738113$.

Maesa, Di Francesco, C. 2018. Effectiveness and Primacy of EU Law v. Higher National Protection of Fundamental Rights and National Identity a Look through the Lens of the Taricco II Judgment. Freiburg: EUCRIM. DOI: https://doi.org/10.30709/eucrim-2018-003.

Mattli, W. and Slaughter, A. 1998. Revisiting the European Court of Justice. International Organization, 52(1), pp.177-209. DOI: 10.1162/002081898550590

Mohay, A. 2020. I came in here for an argument! The German Federal Constitutional Court's ruling on the PSPP programme and the authority of EU law. Pécs Journal of International and European Law - 2020/I. pp.6-8.

Norberg, A. 2006. Preliminary rulings and the cooperation between national and European Courts/master thesis. Lund: University of Lund.

Oliver, P. 1994. The French Constitution and the Treaty of Maastricht. The International and Comparative Law Quarterly, 43(1), pp.1-25.

Paunio, E. 2010. Conflict, power, and understanding - judicial dialogue between the ECJ and national courts, Helsinki: NoFo 7. Available at: http://www.helsinki.fi/nofo/NoFo7Paunio. pdf (29.08.2020).

Peročević, K. 2017. European Union Legal Nature: EU as Sui Generis - A Platypus-Like Society. InterEULawEast Journal for the International and European Law, Economics and Market Integrations, 4(2), pp.101-116. DOI: 10.22598/iele.2017.4.2.7.

Rosas, A. 2007. The European Court of Justice in Context: Forms and Patterns of Judicial Dialogue. European Journal of Legal Studies, 1(2), pp.1-16.

Sadurski W. 2006. Solange, chapter 3: Constitutional Courts in Central Europe-DemocracyEuropean Union. Florence: EUI Working Paper LAW No. 2006/40.

Sarmiento, D and Utrilla, D. 2020. Germany's Constitutional Court has gone nuclear. What happens next will shape the EU's future. EURONEWS. Available at: https://www. euronews.com/2020/05/15/germany-constitutional-court-gone-nuclear-what-happensnext-will-shape-the-eu-future-view (10.09.2020). 
Shkarikj, S. 2008. Evropskoto ustavno pravo I evropeizacijata na makedonskoto ustavno pravo. In: Kambovski, V, Mirchev, D. and Shkarikj, S. Evolucijata na ustavniot system na Republika Makedonija vo presret na usvojuvanjeto na Ustavniot dogovor na Evropskata Unija. Skopje: MANU, pp.27-56.

Steiner, J., Woods, L. and Twigg-Flesner, C. 2003. Textbook on EC law ( $8^{\text {th }}$ ed). Oxford: Oxford University Press.

Svensson, S. 2008. European Integration and the ECJ: The role of the European Court of Justice in the integration of the European Community. Lund: Lund University Libraries. Available at: http://lup.lub.lu.se/student-papers/record/1316466 (12.08.2020).

Van Rossem, J. N. 2013. The autonomy of EU Law: More is less?. In: Wessel, R. A. and Blockmans, S. (eds.). Between Autonomy and Dependence. The Hague: T.M.C. Asser Press, pp.13-46.

Vauchez, A. 2008. Integration-through-Law: Contribution to a Socio-history of EU Political Common Sense. Florence: EUI Working Papers RSCAS 2008/10. Available at: https:// cadmus.eui.eu//handle/1814/8307 (12.08.2020).

Vincenzi, C. and Fairhurst, J. 2002. Law of the European Community ( $3^{\text {rd }}$ ed). London: Longman Pearson Publishers.

Weatherill, S. 1993. EC Law, The Essential Guide to the Legal Workings of the European Community. London: Blackstone.

Weiler, J. 1981. The Community System: the Dual Character of Supranationalism. Yearbook of European Law, 1(1), pp.267-306. DOI: 10.1093/yel/1.1.267.

Weiler, J. 1994. A Quiet Revolution: The European Court of Justice and Its Interlocutors. Comparative Political Studies, 26(4), pp.510-534.

DOI:10.1177/0010414094026004006.

Witte, B. 1991. Community Law and National Constitutional Values. Legal Issues of European Integration, 18(2), pp.1-22.

Witte, B. 1999. Direct Effect, Primacy, and the Nature of the Legal Order. In: Craig, P. and De Búrca, G. (eds.), The Evolution of EU Law, Oxford/New York: Oxford University Press, pp.177-213.

Witte, B. 2011. Direct Effect, Primacy, and the Nature of the Legal Order. In: Craig, P. and De Búrca, G. (eds.), The Evolution of EU Law, Oxford/New York: Oxford University Press, pp.323-362.

\section{LEGAL SOURCES AND CASE LAW}

Case C-26/62, NV Algemene Transporten Expeditie Onderneming van Gend en Loos v Nederlandse Administratie der Belastingen [1963] ECR 1. 
Case C-6/64, Flaminio Costa v ENEL [1964] ECR 585, 593.

Case C-11/70, Internationale Handelsgesellschaft mbH v. Einfur und Vorratsstelle fur Getreide und Futtermittel, [1970] ECR 1125.

Case C-106/77, Amministrazione delle Finanze dello Stato v. Simmenthal SpA, [1978] ECR 629.

Case C-213/89, $R v$. Secretary of State for Transport, ex parte Factortame Ltd. and Others, [1990] ECR I-2433.

Case C-105/14, Ivo Taricco and Others, ECJ (Grand Chamber) 8 September 2015.

Case C-42/17, M.A.S. and M.B., ECJ (Grand Chamber) 5 December 2017, (also known as Taricco II).

Fromagerie Franco-Suisse Le Ski v. Etat Belge [1972] CMLR 330.

Frontini v Ministero delle Finanze [1974] 2 CMLR 372.

Spa Fragd v Amministrazione delle Finanze, Dec 232 of 21 Apr 1989 (1989) 72 RDI.

Dec of 24 May 1975 in Administration des Douanes v Société 'Cafés Jacques Vabre' et SARL Weigel et Cie [1975] 2 CMLR 336.

Dec of 20 Oct 1989 in Raoul Georges Nicolo [1990] 1 CMLR 173.

BVerfG, case 2 BvL 52/71, Solange I, order of 29 May 1974.

BVerfG, case 2 BvR 197/83, Solange II, order of 22 Oct. 1986.

BVerfG, case 2 BvR 2134, 2159/92, Treaty of Maastricht, judgment of 12 Oct. 1993.

BVerfG, 2 BvR 2661/06, 6 July 2010.

BVerfG, case 2 BvE 2/08 et al., Treaty of Lisbon, judgment of 30 June 2009.

BverfG, Judgment of the Second Senate of 05 May 2020 - 2BvR 859/15.

Polish Constitutional Tribunal, 27 Apr 2005, No P 1/05.

Judgment U-VIIR-1159/2015, 8 April 2015 of the Croatian Constitutional Court; Judgment U-VIIR-1158/2015, 21 April 2015 of the Croatian Constitutional Court.

Treaty of Maastricht on European Union. OJ C 191, 29.7.1992.

Treaty of Nice amending the Treaty on European Union, the Treaties establishing the European Communities. OJ C 080, 10/03/2001.

Treaty of Amsterdam amending the Treaty on European Union, the Treaties establishing the European Communities. OJ C 340, 10.11.1997.

Treaty of Lisbon amending the Treaty on European Union and the Treaty establishing the European Community. OJ C 306, 17.12.2007. 


\section{OFFICIAL STATEMENTS}

PRESS RELEASE No. 58/20 following the judgment of the German Constitutional Court of 5 May 2020. Court of Justice of the European Union, Luxembourg, 8 May 2020. Available at:https://curia.europa.eu/jcms/upload/docs/application/pdf/2020-05/cp200058en.pdf (10.09.2020).

PRESS RELEASE - ECB takes note of German Federal Constitutional Court ruling and remains fully committed to its mandate. European Central Bank, Frankfurt am Main, 5 May 2020. Available at: https://www.ecb.europa.eu/press/pr/date/2020/html/ecb. pr200505 00a09107a9.en.html (10.09.2020).

PRESS RELEASE - Statement by President VON DER LEYEN. European Commission, Brussels, 10 May 2020. Available at: https://ec.europa.eu/commission/presscorner/ detail/en/STATEMENT_20_846 (10.09.2020). 